\title{
Hubungan antara Job Characteristic dengan Perilaku Cyberloafing pada Karyawan Tenaga Kependidikan Biro Akademik dan Kemahasiswaan di Universitas Andalas
}

\author{
Herio Rizki Dewinda, Syarifatul Hidni Rafli, Ria Okfrima \\ Fakultas Psikologi, Universitas Putra Indonesia "YPTK" Padang, Indonesia \\ Email: $\underline{\text { hrdewinda@gmail.com, syarifatulhidnirafli@gmail.com, ria.okfrima.chan@gmail.com }}$
}

\begin{abstract}
This study aims to determine the relationship between Job Characteristics and Cyberloafing Behavior among Educational Staff at the Academic and Student Affairs Bureau at Andalas University. The independent variable in this study is Job Characteristic and the dependent variable is Cyberloafing. The measuring instrument used in this study was saturated sampling technique. The sample in this study were 45 employees of the Academic and Student Affairs Bureau at Andalas University. Validity and reliability tests in this study used the Aplha Cronbach technique. The results of the validity coefficient on the Job characteristic scale move from rix $=0.347$ to rix $=0.657$ with a reliability coefficient of $\alpha=0.843$. Meanwhile, on the cyberloafing scale, it moves from rix $=0.331$ to rix $=0.670$ with a reliability coefficient of $\alpha=0.898$. Based on data analysis, the correlation value is 0.434 with a positive direction, with a significance level of 0.003, which means that the hypothesis is accepted. This shows that there is a significant positive relationship between job characteristics and cyberlaofing.
\end{abstract}

Keywords: Job Characteristic, Cyberloafing, employees

\begin{abstract}
Abstrak
Penelitian ini bertujuan untuk mengetahui Hubungan Antara Job Characteristic dengan Perilaku Cyberloafing pada Karyawan Tenaga Kependidikan Biro Akademik dan Kemahasiswaan di Universitas Andalas. Variabel bebas dalam penelitian ini adalah Job Characteristic dan variabel terikat adalah Perilaku Cyberloafing. Alat ukur yang digunakan dalam penelitian ini menggunakan teknik sampel jenuh. Sampel dalam penelitian ini adalah 45 orang karyawan Tenaga Kependidikan Biro Akademik dan Kemahasiswaan di Universitas Andalas. Uji validitas dan reliabilitas pada penelitian ini menggunakan teknik Aplha Cronbach. Hasil koefisien validitas pada skala Job characteristic bergerak dari $\mathrm{r}_{\mathrm{ix}}=0,347$ sampai dengan $r_{i x}=0,657$ dengan koefisien reliabilitas sebesar $\alpha=0,843$. Sedangkan pada skala cyberloafing bergerak dari $r_{i x}=0,331$ sampai dengan $r_{i x}=0,670$ dengan koefisien reliabilitas sebesar $\alpha=$ 0,898. Berdasarkan analisis data, diperoleh nilai korelasi sebesar 0,434 berarah positif, dengan taraf signifikansi 0,003, yang berarti hipotesis diterima. Hal ini menunjukkan bahwa terdapat hubungan yang signifikan berarah positif antara job characteristic dengan cyberloafing.
\end{abstract}

Kata kunci : Job Characteristic, Cyberloafing, Karyawan

\section{Pendahuluan}

Sumber daya manusia merupakan faktor yang sangat penting dalam suatu perusahaan. Baik itu perusahaan yang sangat besar maupun perusahaan yang kecil. Hal ini disebabkan karena sumber daya manusia merupakan penggerak seluruh aktivitas yang ada dalam sebuah perusahaan. Sumber daya manusia berperan sebagai pemikir, perencana dan pelaksana seluruh aktivitas yang ada dalam perusahaan. Pengelolaan sumber daya manusia dalam suatu organisasi merupakan hal yang penting. Organisasi yang memiliki sumber daya manusia yang baik, akan memiliki kekuatan kompetitif pada organisasi bisnisnya, menurut Wisantyo dan Madiistriyatno[20]. Oleh karena itu organisasi membutuhkan manajemen sumber daya manusia yang mampu mengelola seluruh sumber daya perusahaan agar dapat berfungsi sesuai dengan apa yang diharapkan perusahaan, baik perusahaan pemerintahan maupun perusahaan swasta.

Keberhasilan sebuah organisasi dalam mencapai tujuan salah satunya ditentukan oleh kinerja pegawainya. Seperti yang diungkapkan oleh Veithzal Rivai [10] bahwa, "Kinerja karyawan 
merupakan suatu hal yang sangat penting dalam upaya perusahaan untuk mencapai tujuannya". Tenaga kerja yang berkualitas tinggi salah satunya didorong oleh semangat kerja yang tinggi. Dengan demikian akan berkontribusi bagi kemajuan dan kelangsungan hidup organisasi. Hal tersebut sangat menunjang terhadap organisasi untuk dapat bertahan hidup di tengah-tengah persaingan yang semakin ketat, dan dapat mencapai tujuan organisasi dengan efektif dan efisien. Peranan sumber daya manusia yang ada pada sebuah organisasi semakin penting seiring dengan semakin kompleksnya tugas, tanggung jawab, dan tantangan yang dihadapi organisasi saat ini. Berbagai tekanan, baik secara fisik maupun psikis, sangat mempengaruhi keadaan mental seorang pegawai dalam suatu organisasi. Rutinitas kerja dalam perputaran waktu yang sangat singkat akan menimbulkan kelelahan, baik secara fisik maupun secara psikis. Keadaan demikian akan menurunkan semangat kerja pegawai yang bersangkutan. Jika organisasi memiliki pegawai yang semangatnya kurang, maka akan menghambat pencapaian tujuan organisasi [10]. Demi menunjang kinerja karyawan dengan perkembangan teknologi, kini telah dikembangkan oleh dan didukung oleh perangkat internet guna meningkatkan teknologi informasi agar suatu organisasi tidak tertinggal dan menjadi setara dengan organisasi-organisasi yang lainnya [17]. Internet merupakan singkatan dari interconnection-networking, dapat diartikan sebagai jaringan kerja yang saling terhubung. Layanan internet juga dapat digunakan pada berbagai bidang, seperti bidang pendidikan, sosial, perbankan, kesehatan, serta pekerjaan atau bisnis. Selain itu, dalam meningkatkan performa karyawan, banyak perusahaan juga telah memanfaatkan fasilitas internet [19]. Performa karyawan dapat meningkat melalui berbagai fasilitas yang diberikan internet dalam mempermudah kinerja karyawan. Disaat akses internet telah menjadi hal yang biasa, maka kecenderungan karyawan untuk menggunakan internet sebagai tujuan hiburan dan tidak berkaitan dengan pekerjaan juga akan semakin meningkat [19]. Sebagai alat yang diakui kehandalanya internet juga berada dalam dua sisi, pada satu sisi menjadi karyawan dalam meningkatkan kinerja, berinteraksi dengan teman, menciptakan inspirasi dan kreativitas pegawai serta membantu pegawai untuk mempelajari banyak hal sementara pada sisi yang lain yaitu munculnya perilaku prokrastinasi kerja pada pegawai yang dapat mengganggu produktivitas kerja pegawai, serta mengembangkan bentuk perilaku menyimpang pada lingkungan kerja, yang salah satunya adalah prokrastinasi kerja karena aktivitas mengakses internet pada jam yang bukan untuk kepentingan pekerjaan itu sendiri dan tentunya berimbas pada hasil kerja [11]. Beberapa keuntungan dari perilaku cyberloafing seperti menghilangkan kebosanan, stres, atau kelelahan, meningkatnya kepuasan kerja, well-being, kebahagiaan pegawai, serta salah satu cara pegawai berekreasi [16]. Kegiatan mengakses internet untuk membuka media sosial, berbelanja online, memeriksa email pribadi dan bermain pada saat jam kerja berlangsung dinyatakan sebagai perilaku cyberloafing. Cyberloafing sendiri adalah perilaku seorang pekerja yang menggunakan internet dengan komputer, desktop, ponsel atau tablet pada saat jam bekerja tengah berlangsung dan tidak ada hubungannya dengan pekerjaan [11]. Dalam survey yang telah dilakukan oleh Asosiasi Penyelenggara Jasa Internet Indonesia (APJII), pengguna fasilitas internet di Indonesia pada tahun 2012 telah tembus hingga mencapai 63 juta jiwa (APJII, 2017) sedangkan pada tahun 2013 menurut APJII serta Badan Pusat Statistik (BPS) mengungkapkan bahwa pengguna internet yang ada di Indonesia mencapai 71,19 juta orang (APJII, 2017) selain itu kebanyakan pelaku penggunaan internet di Indonesia berstatus pekerja dengan menunjukkan hampir $72.41 \%$. (APJII, 2017) dan survey yang terbaru yang telah di lakukan oleh APJII bahwa dari populasi jumlah penduduk Indonesia yang terbaru pada tahun 2016 terdapat hingga 132,7 juta jiwa pengguna dan internet di tahun 2017 diketahui melonjak tinggi bahkan dalam surveynya terdapat 143,26 juta jiwa pengguna jasa internet aktif di Indonesia (APJII, 2017) dari data yang di hasilkan di dapatkan hasil bahwa pengguna internet dari tahun ke tahun di ketahui meningkat dengan sangat cepat. Terdapat banyak faktor yang melatar belakangi terjadinya perilaku cyberloafing menurut Ozler dan Polat [5] yaitu yang pertama adalah faktor individual, meliputi shyness, loneliness, isolation, self control, harga diri dan locus of control, kebiasaan dan adiksi internet, faktor demografis, keinginan untuk terlibat, norma sosial dan kode etik personal. Kemudian faktor kedua adalah organisasi, meliputi pembatasan penggunaan internet, hasil yang diharapkan, dukungan manajerial, pandangan rekan kerja tentang norma cyberloafing, sikap kerja pegawai dan job characteristic yang pegawai lakukan. Sedangkan faktor yang ketiga adalah situasional, meliputi kedekatan jarak ruangan pegawai dan kedekatan dengan atasan. 
Salah satu aspek yang paling mendasar dalam pengelolaan orang-orang (pegawai) dalam organisasi adalah yang berkaitan dengan pengelolaan sikap kearah yang positif, sehingga karakteristik pekerjaan dan motivasi ekstrinsik pegawai dapat mencapai hasil yang positif pula dalam peningkatan kinerja pegawai tersebut. Secara teoritik, ciri-ciri karakteristik kerja pegawai ditentukan oleh berbagai variabel yang berkaitan dengan keragaman keterampilan, jati diri tugas, makna tugas, otonomi dan umpan balik [17]. Job characteristic atau karakteristik pekerjaan didefinisikan sebagai atribut tugas karyawan dan meliputi sejumlah tanggung jawab, berbagai tugas, dan sejauh mana pekerjaan itu memiliki karakteristik yang dapat membuat karyawan merasakan kepuasan [13]. Hackman dan Oldham mendefinisikan Karakteristik Pekerjaan sebagai aspek internal dari suatu pekerjaan itu sendiri yang mengacu pada isi dan kondisi dari pekerjaan itu sendiri [7]. Chiu \& Chen (dalam Rahmi \& Riyono, 2016) mendefinisikan karakteristik pekerjaan atau job characteristic sebagai atribut pekerjaan yang memiliki fungsi motivasi bagi para karyawan. Motivasi internal terjadi ketika individu melakukan pekerjaannya karena perasaan positif yang dihasilkan ketika melakukan pekerjaan dengan baik [18]. Keberadaan internet bagi karyawan seolah menjadi keuntungan tersendiri.penerapan komputerisasi dan internet telah berefek terhadap kemalasan karyawan, harapan dari suatu organisasi, dengan berkembangnya infrastruktur secara kualitas dan kuantitas justru disalah gunakan oleh sebagian karyawan. Terdapat banyak fakta di lapangan yang membuktikan bahwa bahwa inventaris yang sudah disediakan oleh suatu organisasi justru dimanfaatkan untuk kepentingan pribadi para karyawan [1] Sebagai Contoh perilakunya adalah menggunakan telepon milik organisasi untuk keperluan pribadi, menggunakan fasilitas organisasi untuk keperluan pribadi, bahkan yang sekarang sedang hangat di perbincangkan adalah cyberloafing. Berdasarkan wawancara awal pada tanggal 11 Maret 2020 dengan salah seorang karyawan yang berada di Biro Kependidikan dan Kemahasiswaan di Universitas Andalas. Fasilitas internet yang ada di Biro Kependidikan dan Kemahasiswaan ini digunakan untuk mempermudah dalam mengirim dan menerima suratsurat yang diberikan dari bawahan kepada atasan dan juga dalam mengirim email lebih mudah, serta untuk mengakses kepentingan dalam mengerjakan pekerjaan juga lebih mudah dengan ada fasilitas internet ini. Fasilitas internet juga bertujuan untuk mengidentifikasi konsekuensi dari karakteristik/ciri khas yang dapat menimbulkan motivasi instrinsik dalam suatu tugas. Menurut observasi yang peneliti lakukan pada saat mewawancarai salah seorang karyawan tersebut faktanya ada beberapa karyawan yang menggunakan fasilitas internet ini dipergunakan untuk kepentingan diri sendiri, untuk hiburan dan ada juga yang membuka situs untuk keperluan tugas kerja, kegiatan seperti membuka YouTube, facebook, dan sejenisnya.

\subsection{Perilaku Cyberloafing}

Salah satu fenomena yang muncul bersamaan dengan penggunaan fasilitas internet ditempat kerja adalah perilaku cyberloafing. Ada banyak istilah lain yang artinya mirip dengan cyberloafing yaitu cyberslacking, non-work related computing, cyberbludging, on-line loafing, internet deviance, problematic internet use, personal web usage at work, internet dependency, internet abuse, serta internet addiction [8]. Perilaku cyberloafing merupakan perilaku kerja pegawai yang bersifat counterproductive dan dapat merugikan instasi pemerintahan. Hal ini dikarenakan perilaku cyberloafing membuat banyaknya pekerjaan yang tertunda dan tidak optimalnya kinerja pegawai negeri sipil bagian administrasi dalam menyelesaikan tugas-tugasnya disebabkan oleh fasilitas internet dari instansi pemerintahan yang tidak terbatas sehingga menggunakan fasilitas internet untuk kepentingan pribadi disaat jam kerja sedang berlangsung. Perilaku yang dilakukan oleh pegawai tersebut dikenal dengan sebutan Perilaku cyberloafing. Cyberloafing didefiniskan sebagai karyawan pengguna internet perusahaan untuk melaksanakan tugas pribadi selama jam kerja [3]. Lebih jauh lagi, definisi konstruk cyberloafing diperjelas menjadi tindakan karyawan yang disengaja dengan penggunaan akses internet milik perusahaan selama jam kerja untuk browsing situs-situs untuk tujuan pribadi dan memeriksa (termasuk menerima dan mengirim) e-mail personal. Kelompok situs hiburan seperti Facebook, YouTube, dan Netflix dikategorikan sebagai "situs yang tidak berkaitan dengan pekerjaan". 


\subsection{Dimensi Perilaku Cyberloafing}

Van Doorn [24] merangkum berbagai dimensi perilaku cyberloafing berdasarkan penelitianpenelitian sebelumnya. Adapun dimensi cyberloafing yang telah dirangkum Van Doorn adalah sebagai berikut:

a. Cyberloafing terdiri dari 5 aktivitas, yaitu: pembayaran dan bisnis personal; mencari dan melihat informasi; komunikasi interpersonal; hiburan yang interaktif dan menghabiskan waktu; Pengunduhan personal.

b. Mahatanankoon mengungkapkan bahwa cyberloafing terdiri dari 4 aktivitas yaitu komunikasi personal, pencarian informasi personal, pengunduhan personal, dan $e$ commercepersonal.

c. Menurut Blau, Yang dan Ward-Cook dimensi cyberloafing dibagi berdasarkan aktivitas yang dilakukan yaitu aktivitas emailing, aktivitas penjelajahan situs web, dan aktivitas interaktif.

d. Lim mendefinisikan dimensi cyberloafing juga didasarkan pada jenis aktivitas yang dilakukan yaitu aktivitas browsing dan aktivitas emailing. (1) Aktivitas browsing merupakan kegiatan karyawan untuk menjelajah berbagai situs web yang tidak berkaitan dengan pekerjaannya. Adapun situs web tersebut antara lain situs yang berhubungan dengan investasi, olahraga, dan hiburan; (2) Aktivitas emailing adalah kegiatan karyawan meliputi mengirim serta memeriksa surat elektronik personal selama jam kerja.

\subsection{Job Characteristic}

Karakteristik pekerjaan (job characteristic) adalah aspek internal pekerjaan yang mengacu pada isi dan pengurangan pekerjaan. Upaya untuk mengidentifikasi karakteristik dari tugas-tugas di pekerjaan, bagaimana karakter ini dikombinasikan untuk menciptakan posisi yang berbeda, menjadi menarik dan juga menciptakan makna pada pekerja. Karakteristik pekerjaan adalah sifat yang berbeda antara jenis pekerjaan yang satu dengan pekerjaan lain yang khusus dan merupakan pekerjaan inti yang mengandung sifat-sifat yang ada di semua pekerjaan dan dirasakan oleh pekerja sehingga mempengaruhi perilaku kerja pekerjaan tersebut. Indikator yang digunakan untuk mengukur karakteristik pekerjaan (Job Characteristic) dalam penelitian ini menggunakan indikator yang digunakan oleh Hackman dan Oldham [15], yaitu Skill Variety, Task Identity, Task significance, Autonomy, dan Feedback.

\subsection{Dimensi Job Characteristic}

Job characteristic merupakan dimensi pekerjaan yang memiliki efek tertentu pada keadaan psikologis karyawan dan menentukan hasil pekerjaan karyawan seperti kepuasan kerja. Kelima dimensi job characteristics menurut Hackman \& Oldham, yaitu (a) Skill Variety (Ragam keahlian) Skill variety merupakan tingkatan dimana pekerjaan memerlukan berbagai kegiatan yang berbeda dalam melakukan pekerjaan yang melibatkan sejumlah keterampilan yang berbeda dan bakat seseorang. Griffin [6] mengatakan bahwa skill variety adalah jumlah pekerjaan yang dilakukan seseorang dalam suatu pekerjaan. Semakin beragam keterampilan yang digunakan karyawan, maka tingkat kebosanan akan pekerjaan berkurang. Pekerjaan yang memiliki variasi yang rendah akan menimbulkan kebosanan. Semakin tinggi kebosanan dapat menimbulkan kelelahan yang berujung pada kesalahan dalam melakukan pekerjaan. (b) Task Identity (Identitas Tugas) Task identity merupakan sejauh mana pekerja dapat menyelesaikan suatu bagian dari keseluruhan pekerjaan atau menyelesaikan suatu bagian yang dapat diidentifikasikan dari keseluruhan pekerjaan [6]. Task identity dapat memungkinkan karyawan untuk melaksanakan pekerjaannya secara utuh. (c) Task Significance (Signifikansi Tugas) Task significance merupakan tingkatan dimana pekerjaan memiliki pengaruh pada hidup atau pekerjaan orang lain, baik dalam organisasi langsung maupun lingkungan luar organisasi. Griffin [6] mengungkapkan bahwa task significance adalah mempersepsikan tugas menjadi hal yang penting. (d) Autonomy (Otonomi) Autonomy merupakan tingkatan dimana pekerjaan menyediakan kebebasan, kemandirian, dan keleluasaan untuk individu dalam menentukan jadwal pekerjaan dan dalam menentukan prosedur yang harus digunakan dalam melaksanakan pekerjaannya. Menurut Griffin 
[6], autonomy adalah tingkat pengendalian yang dimiliki pekerja mengenai bagaimana pekerjaan itu dilaksanakan. (e) Feedback (Umpan Balik), Griffin [6], Feedback merupakan sejauh mana pekerja mengetahui seberapa baik pekerjaan telah dilaksanakan.

\section{Metode Penelitian}

Jenis penelitian ini adalah kuantitatif korelasional dengan variabel penelitian menurut Sugiyono [21] Variabel Dependen, penelitian Cyberloafing (Y) dan Variabel Independen, Job Characetistic (X). Populasi pada penelitian ini adalah karyawan Tenaga Kependidikan Biro Akademik dan Kemahasiswaan di Univeristas Andalas yang berjumlah 45 karyawan. Teknik pengambilan sampel dalam penelitian ini adalah sampling jenuh karena teknik penentuan sampel bila semua anggota populasi digunakan sebagai sampel [21] sehingga diperoleh 45 karyawan sebagai sampel penelitian.

Metode pengumupulan data yang digunakan dalam penelitian ini adalah skala model likert untuk mendapatkan data kuantitatif. Skala ini digunakan untuk mengukur sikap, pendapat, dan persepsi seseorang atau sekelompok orang tentang fenomena sosial [21]. Skala yang digunakan pada penelitian ini yaitu Skala Perilaku Cyberloafing dan Skala Job Characteristic. Format skala yang digunakan merupakan format yang telah dimodifikasi menjadi empat alternatif jawaban yaotu SS (Sangat Setuju), S (Setuju), TS (Tidak Setuju). STS (Sangat Tidak Setuju). Aitemaitem dalam skala ini dikelompokkan dalam item favorable dan unfavorable. Skala penelitian akan melewati berbagai tahap analisis yaitu uji normalitas digunakan untuk mengetahui apakah populasi data terdistribusi normal atau tidak. Uji normalitas menggunakan uji KolmogorovSmirnov. Uji linearitas bertujuan untuk mengetahui apakah dua variabel mempunyai hubungan yang linear atau tidak. Dua variabel dikatakan mempunyai hubungan yang linear bila signifikansi (linearity) kurang dari 0,05.

Selain itu dilakukan uji validitas, sejauh mana ketepatan dan kecermatan suatu alat ukur dalam melakukan fungsi ukurnya [4]. Suatu item dapat dianggap memiliki daya diskriminasi yang memuaskan jika berkorelasi signifikan terhadap skor total atau jika melakukan penilaian langsung terhadap koefisien korelasi bisa digunakan batas nilai berkriteria $r_{x y} \geq 0,3$ [4]. Data skala dikatakan memiliki daya beda tinggi jika koefisien korelasi lebih besar atau sama dengan $0,3\left(r_{x y} \geq 0,3\right)$ dan sebaliknya aitem skala dikatakan gugur jika koefisien korelasi lebih kecil dari $0,3\left(r_{x y} \geq 0,3\right)$.

\section{Hasil dan Pembahasan}

\subsection{Hasil}

Koefisien validitas skala perilaku cyberloafing dengan nilai corrected item-total correlation berkisar antara 0,347 sampai dengan 0,567, dengan reabilitas 0,843 , validitas skala job characteristic dengan nilai corrected item-total correlation berkisar antara 0,331 sampai dengan 0.670, dengan reabilitas 0,898. Uji normalitas dalam penelitian ini menggunakan uji Kolmogorov-Smirnov, Priyatno [14] menyatakan bahwa data yang dinyatakan berdistribusi normal jika signifikansi (p) lebih besar dari 0,05. Berdasarkan hasil pengolahan data dengan menggunakan program IBM SPSS 22.0, Maka diperoleh hasil sebagai berikut:

Tabel 1. Uji Normalitas Skala Job Characteristic dengan Perilaku Cyberloafing

\begin{tabular}{ccccc}
\hline Variabel & N & KSZ & P & Sebaran \\
\hline Job Characteristic & 45 & 0,095 & 0,200 & Normal \\
Cyberloafing & 45 & 0,120 & 0,102 & Normal \\
\hline
\end{tabular}

Berdasarkan uraian tabel diatas, maka diperoleh nilai signifikan pada skala job characteristic diperoleh dengan nilai signifikan sebesar $\mathrm{p}=0,200$ dengan $\mathrm{KSZ}=0,095$ hasil tersebut menunjukkan bahwa nilai $\mathrm{p}>0,05$ artinya sebaran berdistribusi secara normal, sedangkan skala perilaku cyberloafing sebesar $\mathrm{p}=0,102$ dengan $\mathrm{KSZ}=0,120$. Hasil tersebut menunjukkan bahwa nilai $p>0,05$ artinya sebaran berdistribusi secara normal. Selanjutnya uji linearitas dapat dilihat pada tabel 2 berikut: 
Tabel 2. Uji Linearitas Skala Job Characteristic dengan Perilaku Cyberloafing

\begin{tabular}{ccccc}
\hline $\mathbf{N}$ & $\mathbf{D f}$ & Mean Square & F & Sig \\
\hline 45 & 1 & 286,026 & 7,268 & 0,013 \\
\hline
\end{tabular}

Berdasarkan uraian tabel di atas, maka diperoleh nilai signifikansi sebesar $\mathrm{p}=0,030(\mathrm{p}<0,05)$. Dapat disimpulkan bahwa antara variabel job characteristic dengan perilaku cyberloafing terdapat hubungan yang linear.

Tabel 3. Hasil Uji Korelasi Skala Job Characteristic dengan Perilaku Cyberloafing

\begin{tabular}{ccccl}
\hline Nilai korelasi $(\mathbf{r})$ & $(\boldsymbol{\alpha})$ & R Square & $\mathbf{P}$ & \multicolumn{1}{c}{ Kesimpulan } \\
\hline 0,434 & 0,01 & 0,189 & 0,003 & $\begin{array}{l}\text { Sig (2-tailed) } 0,003<0,01 \text { level of } \\
\text { significant }(\alpha), \text { berarti hipotesis diterima. }\end{array}$
\end{tabular}

Berdasarkan uraian Tabel 3 di atas, maka diperoleh koefisien korelasi antara job characteristic dengan perilaku cyberloafing $(r)=0,434$ dengan taraf signifikansi $p=0,003(p<0,05)$. Maka dapat disimpulkan bahwa ada hubungan antara job characteristic dengan perilaku cyberloafing pada karyawan Tenaga Kependidikan Biro Akademik dan Kemahasiswaan di Universitas Andalas. Hal ini menunjukkan semakin tinggi job characteristic maka semakin tinggi pula perilaku cyberloafing pada karyawan. Begitupun sebaliknya, semakin rendah job characteristic maka semakin rendah pula perilaku cyberloafing pada karyawan.

Tabel 4. Descriptive Statistic

\begin{tabular}{cccccc}
\hline Variable & N & Mean & Std. Deviation & Minimum & Maximum \\
\hline Job Characteristic & 45 & 59,44 & 6,604 & 19 & 76 \\
Cyberloafing & 45 & 68,96 & 5,870 & 25 & 100 \\
\end{tabular}

Berdasarkan nilai mean hipotetik tersebut, maka dapat dilakukan pengelompokkan yang mengacu pada kriteria pengkategorisasian dengan tujuan menempatkan individu ke dalam kelompokkelompok yang terpisah secara berjenjang menurut kontinum berdasarkan atribut yang diukur (Azwar, 2014).

Tabel 5. Kategorisasi Job Characteristic dengan Perilaku Cyberloafing

\begin{tabular}{clccc}
\hline Variabel & Skor & Jumlah & Presentase (\%) & Kategori \\
\hline Job Characteristic & $19-51$ & 4 & $9 \%$ & Rendah \\
& $52-65$ & 34 & $76 \%$ & Sedang \\
& $66-76$ & 7 & $15 \%$ & Tinggi \\
Perilaku Cyberloafing & $25-63$ & 7 & $15 \%$ & Rendah \\
& $64-74$ & 26 & $58 \%$ & Sedang \\
& $75-100$ & 12 & $27 \%$ & Tinggi \\
\hline
\end{tabular}

Berdasarkan Tabel 5 di atas, dapat digambarkan bahwa terdapat sebanyak 4 orang (9\%) karyawan memiliki job characteristic yang rendah, 34 orang (76\%) karyawan memiliki job characteristic yang sedang, dan sebanyak 7 orang $(15 \%)$ karyawan memiliki job characteristic yang tinggi.

Sementara itu terdapat sebanyak 7 orang (15\%) karyawan memiliki perilaku cyberloafing yang 
rendah, 26 orang (58\%) karyawan memiliki perilaku cyberloafing yang sedang, dan sebanyak 12 orang (27\%) karyawan memiliki perilaku cyberloafing yang tinggi.

\subsection{Pembahasan}

Penelitian ini bertujuan untuk mengetahui hubungan antara job characteristic dengan perilaku cyberloafing pada karyawan di Biro Akademik dan Kemahasiswaan Universitas Andalas. Berdasarkan uji hipotesis yang dilakukan menunjukkan bahwa terdapat hubungan yang signifikan antara job characteristic dengan perilaku cyberloafing pada karyawan Tenaga Kependidikan Biro Akademik dan Kemahasiswaan di Universitas Andalas diperoleh nilai koefisien korelasi $r=0,434$ dengan nilai $p=0,003$, karena nilai (p) sig $<0,01$ maka hipotesis diterima. Hasil ini menunjukkan bahwa terdapat hubungan dengan arah positif antara job charateristic dengan perilaku cyberloafing pada karyawan Tenaga Kependidikan Biro Akademik dan Kemahasiswaan di Universitas Andalas, artinya semakin tinggi job characteristic, maka semakin tinggi pula perilaku cyberloafing pada karyawan, sebaliknya semakin rendah job characteristic, maka semakin rendah perilaku cyberloafing pada karyawan. Hasil uji hipotesis ini menunjukkan arah positif bisa terjadi karena beberapa penyebab adanya kelemahan dalam penelitian ini, seperti dalam pengisian skala yang kurang cermat atau tepat, waktu menyebarkan skala yang tidak tepat, latar belakang subjek yang mengisi skala, dan faktor lainnya yang menyebabkan hal tersebut bisa terjadi.

Hasil uji hipotesis tersebut bahwa salah satu faktor yang menyebabkan karyawan mengalami perilaku cyberloafing adalah job characteristic. Ozlar dan Polat [12] mengatakan bahwa faktor organisasi juga dapat menentukan kecenderungan pegawai untuk melakukan cyberloafing yaitu pembatasan penggunaan internet, hasil yang diharapkan, dukungan manajerial, pandangan rekan kerja tentang norma cyberloafing, sikap kerja pegawai dan karakteristik pekerjaan atau job characteristic yang pegawai lakukan.

Hasil penelitian ini memiliki perbedaan dengan penelitian yang dilakukan oleh Putriani [17] tentang Hubungan antara Job Characteristic dengan Perilaku Cyberloafing pada Karyawan di PT TKMA yang menunjukkan bahwasanya adanya hubungan yang signifikan dengan arah negatif antara job characteristic dengan perilaku cyberloafing pada karyawan PT TKMA. Hal ini berarti semakin positif job characteristic maka semakin rendah perilaku cyberloafing pada karyawan, sebaliknya semakin negatif job characteritic maka semakin tinggi perilaku cyberloafing.

Dilihat dari penilaian deskriptif terhadap 45 orang karyawan Tenaga Kependidikan Biro Akademik dan Kemahasiswaan di Universitas Andalas, digambarkan bahwa terdapat sebanyak 4 orang $(9 \%)$ karyawan memiliki job characteristic yang rendah, 34 orang $(76 \%)$ karyawan memiliki job characteristic yang sedang, dan sebanyak 7 orang (15\%) karyawan memiliki job characteristic yang tinggi. Sementara itu terdapat sebanyak 7 orang (15\%) karyawan memiliki perilaku cyberloafing yang rendah, 26 orang (58\%) karyawan memiliki perilaku cyberloafing yang sedang, dan sebanyak 12 orang (27\%) karyawan memiliki perilaku cyberloafing yang tinggi.

Adapun sumbangan efektif dari variabel job characteristic terhadap perilaku cyberloafing adalah sebesar $19 \%$ dan $81 \%$ lagi dipengaruhi oleh faktor lain, seperti penelitian sebelumnya yang menunjukkan bahwa karyawan yang menganggap penggunaan internet itu bermanfaat bagi kinerjanya secara keseluruhan, lebih mungkin untuk terlibat dalam melakukan cyberloafing dari pada yang lain [23].

\section{Kesimpulan}

Berdasarkan hasil dan pembahasan yang telah dijelaskan pada bab sebelumnya, maka dapat ditarik kesimpulan yang sekaligus merupakan jawaban dari tujuan penelitian yaitu terdapat hubungan yang signifikan antara Job Characteristic dengan Perilaku Cyberloafing pada Karyawan Tenaga Kependidikan Biro Akademik dan Kemahasiswaan di Universitas Andalas dengan arah positif, artinya jika job characteristic tinggi, maka perilaku cyberloafing pada karyawan Tenaga Kependidikan Biro Akademik dan Kemahasiswaan tinggi, dan sebaliknya jika job characteristic rendah, maka perilaku cyberloafing pada karyawan tenaga kependidikan biro akademik dan kemahasiswaan rendah. Adapun sumbangan efektif dari variabel antara job characteristic dengan perilaku cyberloafing yaitu sebesar $19 \%$.

\section{Daftar Rujukan}


[1] Ardilasari, N., Firmanto, A. (2017). "Hubungan antara Self Control dan Perilaku Cyberloafing pada Pegawai Negeri Sipil”. Jurnal Ilmiah Psikologi Terapan. Universitas Muhammadyah Malang.

[2] Askew, K. (2012). "The relationship between cyberloafing and task performance and an examination of the theory of planned behavior as a model of cyberloafing". Dissertations. University of South Florida.

[3] Astri, Y., Zahrani, S. (2017). "Pengaruh Iklim Organisasi Terhadap Perilaku Cyberloafing pada Karyawan PT X". Jurmal Pemikiran \& Penelitian Psikologi. Vol.13, No.1. hal 16-26. Universitas Sumatera Utara.

[4] Azwar, S. (2012). "Penyusunan Skala Psikologi”. Yogyakarta: Pustaka Belajar.

[5] Budiana, F.A. (2018). "Hubungan antara Loneliness denga Perilaku Cyberloafing pada Karyawan". Skripsi. Surabaya: Universitas Negeri Sunan Ampel Surabaya.

[6] Griffin, R.W. (2004). "Manajemen Edisi 7, Jilid 1". Jakarta: Erlangga.

[7] Istighfarin, L.N., Mulyana, O.P. (2018). "Hubungan antara Persepsi Terhadap Karakteristik Pekerjaan dengan Semangat Kerja pada Karyawan PT.X”. Jurnal Psikologi Pendidikan. Vol. 5, No.1. Universitas Negeri Surabaya.

[8] Kim, S.J., \& Byrne, S. (2011). “Conceptualizing personal web usage in work contexts: a preliminary framework". Computers in Human Behavior, 27, 2271-2283.

[9] Lim, V.K., Chen, D.J. (2012). "Cyberloafing at the workplace: gain or drain on wrok?”. Published in Behavior \& Information Technology. Singapore Management University.

[10] Masharyono. (2015). "Pengaruh Job Characteristics terhadap Semangat Kerja Pegawai (Survey pada Pegawai PNS di Lingkungan Disparbud Jabar)". Jurnal Riset Akuntansi dan Keuangan. Universitas Pendidikan Indonesia.

[11] Mirza, T.AR., Santoso, H. (2019). "Internet dan Perilaku Cyberloafing pada Karyawan". Psikoislamedia Jurnal Psikologi. Vol.4, No.1. Universitas Negeri Ar-Raniry.

[12] Ozler, D. E., Polat, G. (2012). "Cyberloafing Phenomenon in Organizations: Determinants and Impacts". International Journal of e-Bussiness and eGovernment Studies, 4(2), 1-15. Dumlupinar University.

[13] Patrick, A., Setiawan, R. (2018). "Pengaruh Job Involvement dan Job Characteristic terhadap Turnover Intention pada PT Mustika Lestari Indonesia". Agora. Vol. 6, No.2. Universitas Kristen Petra.

[14] Priyatno, S. (2014). "SPPS 22 Pengolah Data Terpraktis". Yogyakarta: C.V. Andi Offset.

[15] Putra, B.N.K., Sudja I.N., Martini, L.K.B. (2018). "The Effect of Job Characteristics and Compensation to Work Satisfaction and Organization Commitment on All Lpd Kerambitan Tabanan”. Universitas Mahasaraswati Denpasar.

[16] Putra, E.Y., Nurtjahjanti, H. (2019). "Hubungan antara Komitmen Organisasi dengan Cyberloafing pada Pegawai Fakultas Teknik Universitas Diponegoro". Jurnal Empati, Vol. 8. No. 2. Universitas Diponegoro.

[17] Putriani, F. (2019). "Hubungan antara Job characteristic dengan Perilaku Cyberloafing pada Karyawan”. Skripsi. Universitas Negeri Sunan Ampel Surabaya.

[18] Rahmi, F., Riyono, B. (2016). "Pengaruh Karakteristik Pekerjaan terhadap Perilaku Kewargaan Organisasi dengan Mediator Nilai-Nilai Kualitas Kehidupan Kerja”. Jurnal Psikologi. Universitas Gadjah Mada. Yogyakarta.

[19] Rahayuningsih, T. (2107). "Perilaku Cyberloafing Ditinjau dari Kecerdasan Adversitas dan Komitmen Kerja”. Jurnal Psikologi. Vol.1. No. 1. Universitas Abdurrab.

[20] Rislisia., Akmal, M.E. (2018). Hubungan Job characteristic dengan turnover Intention pada Karyawan. Jurnal Magister Psikologi. Universitas Prima Indonesia.

[21] Sugiyono. (2014). "Metodologi Penelitian Kuantitatif Kualitatif dan R\&D”. Bandung: Alfabeta.

[22] Utama, J. S. A., dkk. (2016). "Psikologi dan Teknologi Informasi. Seri Sumbangan Pemikiran Psikologi untuk Bangsa". Jakarta: Himpunan Psikologi Indonesia.

[23] Vitak, Jessica, Julia Crouse and Robert LaRose, (2011), "Personal Internet use at work: Understanding Cyberslacking", Computers in Human Behavior, Vol.27, pp.1751-1759.

[24] Wicaksana, S.A. (2019). "Hubungan antara Work Stressor (Role Conflict \& Role Overload) dengan Perilaku Cyberloafing pada Karyawan PT. Darya-Varia Laboratoria TBK”. Skripsi. Universitas Negeri Semarang. 